\title{
СТАНОВА ДВОРЯНСЬКА ОСВІТА В УКРАЇНІ ДРУГОЇ ПОЛОВИНИ ХІХ - ПОЧАТКУ ХХ СТ.: ДОНКІХОТСВО ЧИ ДАНИНА ТРАДИЦІЙНИМ ЦІННОСТЯМ?
}

\author{
В. С. Шандра
}

\begin{abstract}
Шандра В. С. Станова дворянська освіта в Україні другої половини XIX - початку XX ст.: донкіхотство чи данина традиційним цінностям? У статті з'ясовуються чинники, які змушували дворянство оберігати і вдосконалювати станову освіту, незважаючи на спроби верховної влади російської держави надати їй всестанового характеру. Пояснено, що її збереження мотивувалося пошуком спільних інтересів державної влади і дворянства щодо підготовки бюрократичних кадрів, а також бажанням дворянської еліти виховувати дітей у дотримуванні традиційних дворянських цінностей.

Ключові слова: дворянство; станова освіта; кадетський корпус; інститут шляхетних панянок; пансіон-притулок.
\end{abstract}

Шандра В. С. Сословное дворянское образование в Украине второй половины XIX - начала XX в.: донкихотство или дань традиционным ценностям? В статье выясняются факторы, которые заставляли дворянство оберегать и совершенствовать сословное образование, несмотря на намерение верховной власти российского государства придать ей всесословный характер. Объяснено, что ее сохранение мотивировалось поиском общих интересов государственной власти и дворянства по подготовке бюрократических кадров, желанием дворянской элиты воспитывать детей в соблюдении традиционных дворянских ценностей.

Ключевые слова: дворянство; сословное образование; кадетский корпус; институт благородных девиц; пансион-приют.

Shandra V. S. Estate Nobles Education in Ukraine in the Second Half of the $19^{\text {th }}$ and Early $20^{\text {th }}$ Centuries: Donkhichotstvo or Tribute to Traditional Values? The article explores the factors that forced the nobility of Ukrainian provinces to protect and improve the state education, despite the desire of the supreme power of the Russian state to give it all of its nature. It is explained that its preservation was motivated by the common interests of the supreme power and the nobility regarding the preparation of bureaucratic personnel, the desire of the noble elite to raise children in observancing to traditional noble values.

Keywords: nobles; estate education; military school; institute of noble ladies; boarding school-shelter.

Внаслідок ліберальних реформ 1860-1870-х років російська держава мала би здійснити крутий поворот до всестанової організації суспільства. Дворянство, привілейоване становище якого тривалий час плекала верховна влада і освіта якого вважалася суттєвою його ознакою, з розумінням поставилася до іiї наміру ліквідувати станові перегородки, як такі що перешкоджали формуванню громадянського суспільства, базованого на загальнолюдських цінностях. Проте через десятиліття, коли пройшло захоплення ліберальними i демократичними ідеями, певна його частина, особливо та, що не відчула позитивних змін, стурбовано намагалася зберегти станову освіту. І вона досягла певного успіху, переконавши Олександра III у її необхідності. Отже, метою цієї розвідки є з'ясування тих мотивів, які спонукали дворянство оберігати станові освітні традиції, а також оновлювати їх, ігноруючи виклики часу.

Традиційно становими навчальними закладами для юнаків і для другої половини XIX ст. залишалися кадетські корпуси, у яких одночасно надавалася військова підготовка і загальна середня освіта. Відкриті при Миколі I, вони зберігали популярність й успішно продовжували свою діяльність, оскільки їх випускники отримували перший обер-офіцерський чин і відразу направлялися на військову службу. Найстаріший з них в підімперській Україні, був Полтавський, заснований дворянами однойменної, Харківської, Чернігівської i Катеринославської губерній на кошти 3 власних маєтків ${ }^{1}$. Його закладенням малоросійський військовий губернатор Микола Рєпнін, сам вихованець першого кадетського корпусу, прагнув якнайшвидше залучити малоросійське дворянство до розбудови імперії${ }^{2}$ Причому, дворяни усіх губерній неодноразово виділяли кошти на заснування там додаткових 
вакансій․․ Харківське ж створило спеціальний фонд розміром у 10-ти тис. руб. 3 назвою «харківський кадет», інші ж - засновували іменні стипендії4.

На будівництво Київського кадетського корпусу дворянство Південно-Західного краю та Херсонської і Таврійської губерній зібрало до 200 тис. руб. ${ }^{5}$. Не дивлячись на нелояльність польської шляхти, російській владі вдалося змусити її отримувати освіту у Київському кадетському корпусі. Микола I розпорядився, що старші сини особистих дворян будуть відбувати військову службу з рядового якщо до 18-ти років не будуть вчитися або служити і аби цього не сталося, правобережна шляхта відправляла юнаків на навчання до Києва ${ }^{6}$. Там і до початку XX ст. переважали діти поляків, які отримували досить високий рівень знань. За спогадами, хоча би Олексія Ігнатьєва, київські за освітою та виучкою суттєво відрізнялися в кращу сторону від інших кадетів ${ }^{7}$.

У кадетських корпусах, котрі відповідали прагматичним потребам тогочасного дворянства 3 його стилем життя, юнаки отримували ті навички і освіту, яка їм гарантувала у майбутньому кар'єрне зростання на військовій і цивільній службі. Там вдало унормовувалися й поєднувалися освіта і виховання. Кожний клас (корпус) мав свого вихователя Цінувалося те, що у них навчали вишуканим манерам, музиці, танцям ${ }^{9}$, котрі вважалися обов'язковим показником дворянської культури та зразкової публічної поведінки. Більше того, для вдосконалення французької і німецької мов запрошувалися «живі їх носії», педагоги-вихідці з Франції і Пруссії. Та головне було в іншому: там була дисципліна, строгі вимоги, там формувалася особистість 3 християнською мораллю, відданості присязі, складових кодексу дворянської честі. Практично для всіх корпусів характерним було дотримання здорового способу життя. Вважалося, що виховання дітей полягає, перш за все у контролі і строгості, у вмінні дотримуватися порядку і режиму, і що набуті навички гарантуватимуть юнакам щасливе майбутнє. Без цього батьки не уявляли виховання своїх синів, майбутніх офіцерів. Це було особливо зручно для тих із них, хто служив по всій території імперії і не міг фізично приділити увагу своїм дітям.

У Полтавському, крім іншого, значну увагу звертали на російську словесність, за допомогою якої ліквідовувалась малоросійська вимова, а при успішному засвоєнні знань, навчання можна було продовжити у Дворянському полку ${ }^{10}$. Російська освіта була загальнообов'язковою і гарантувала обіймання державних посад, а тому ставала важливим інструментом асиміляційної політики.

Підраховано, що більше $65 \%$ учнів у кадетських корпусах були дітьми спадкових дворян тих, які, як і верховна влада, вважали, що навчання військовій справі $є$ не тільки обов'язком, а й покликанням дворян. А тому виховання базувалося на формуванні цілком конкретних рис характеру особистості юнаків: відданість батьківщині й уміння iї захищати, котрим надавалося значення високої моралі. Важливим було й виховання пошани до батьків, до імператора та імператорської фамілії. Аби любов до рідного краю, якщо говорити про українські губернії, не суперечила загальноімперським інтересам, кадети спеціально вивчали українські народні пісні.

Не можна стверджувати, що дворяни однозначно сприймали спрямованість верховної влади на відкриття кадетських корпусів для підготовки військових кадрів. Малоросійське дворянство пропонувало й інші форми станової освіти. Проект перетворити повітові училища на дворянські п'ятикласні школи запропонував 1841 р. дворянин Роменського повіту Полтавської губернії П. Омельянко, рекомендуючи запровадити там практичне законодавство та геодезію. Перша дисципліна дозволить юнакам стати освіченими чиновниками, а друга - отримати знання для власного землекористування ${ }^{11}$.

Курс Олександра II з 1864 р. на перебудову освіти з наданням їй всестанового характеру, зокрема про запровадження на базі кадетських корпусів військових гімназій, у яких могли навчатися і діти інших соціальних груп, дворянство оцінило по-різному. Полтавське тут же відмовилося фінансувати військову гімназію, уважаючи, куди важливішим було б відкриття таких навчальних закладів, котрі б готували кадри для реформованої судової системи і для розвитку сільського господарства в краї. Проте такого рішення Комітет міністрів не схвалив, уважаючи, що їх утримання буде обтяжливим для імперії, та й дворянство не має права відмовлятися від взятих свого часу зобов'язань щодо їх фінансування ${ }^{12}$. Більшість дворян підтримало владу, й військові гімназії зберігали станово-дворянський склад, випускникам яких надавалась можливість без екзаменів вступати до військових училищ ${ }^{13}$. 
Відмова від військових гімназій і повернення до кадетських корпусів за Олександра III 1882 р. була сприйняти дворянством як сигнал до відновлення станової освіти. Саме цим пояснюється відкриття нових кадетських корпусів - Сумського в 1899 і Одеського 1900 рр. Сумський кадетський корпус заснував на власні кошти цукрозаводчик, місцевий громадський діяч Іван Харитоненко, який виділив і кошти, і землю під забудову кадетських корпусів. У заповіті він так пояснив свій вчинок: «Из любви к моей родине» ${ }^{14}$. Тоді ж з'явилась пропозиція і у чернігівського дворянства, відкрити у губернському місті кадетський корпус. Ї̈і обгрунтування є показовим для розуміння мотивів дворянства здобувати освіту у кадетських корпусах. Дворян не влаштовувала програма навчання у гімназії, де забагато часу відводилося на латину і старогрецьку мови, які не варті такої уваги. Тим більше, що їх знання непрактичні і вони навряд чи знадобляться у майбутньому випускникам гімназії. Крайній класицизм перетворював там навчання у «важку школу лінгвістичної схоластики», яку не можуть здолати діти із нерозвиненою пам'яттю. Через це гімназії не користувалися довірою у дворян, та й не тільки у них. А от у кадетському корпусі програма навчання хоча й була розрахована на сім років, тут більше ніж у гімназії, зосереджувалися над вивченням математики, природничої історії, космографії і законодавства. До спеціальних занять належали фортифікаційне і топографічне креслення, військова історія. Ці навчальні дисципліни були куди потрібнішими. До того ж кадети отримували мінімум знань для розуміння мистецтва, художнього слова та культури поведінки. Василь Варзер, схиляючи Чернігівське губернське дворянське зібрання до заснування кадетського корпусу, звертав увагу на те, що його середовище традиційно віддає перевагу військовим професіям. 3 іншого боку, доступ у гімназії дітям із шляхетних родин закривають «природні лінгвісти», якими він вважав євреїв і греків ${ }^{15}$.

Брак коштів у губернського дворянського зібрання, неприйняття вищою адміністрацією пропозиції зупинило ініціативу. Однак, враховуючи ці та подібні настрої, а також потребу у військових, адже імперія не відмовилася від участі у воєнних конфліктах і продовжувала нарощувати військову присутність на державних кордонах, Військове міністерство заснувало кілька нових кадетських корпусів. Зважаючи на значення міста-порту кадетський корпус був відкритий в Одесі 1899 р. На відміну від інших він відкривався одночасно з Варшавським уже на державні кошти. Кожний з них був розрахований на 500 казенних інтернів ${ }^{16}$. Для розміщення Одеського була використана садиба польського поміщика I. Сабанського, конфіскована свого часу за підтримку Січневого 1863 р. повстання. 31915 р. почав функціонувати Севастопольський морський кадетський корпус, у якому переважали діти дворян Херсонської і Таврійської губерній. Крім місцевих кадетських корпусів дворяни могли розраховувати на навчання своїх синів і у інших, зокрема престижних столичних закладах, як-от: училище правознавства та Олександрівський (колишній Царськосельський) ліцей, у котрих перевага віддавалась правовим дисциплінам.

Незважаючи на відкриття, нехай і поступове, майже у кожному місті гімназій і прогімназій більшість дворян прагнули все таки віддати дітей на навчання до кадетських корпусів. Їхні звернення до адміністрації дозволяють з'ясувати соціальне становище прохачів: найчастіше зверталися ті, хто мав багатодітні сім’ї, хто не мав достатньо коштів дати синам і онукам гімназійну і університетську освіту і тому просили зарахувати їх до кадетських корпусів на державний кошт. Малоземельні, а то й безземельні дворяни вважали, що для їхніх дітей освіта була єдиним засобом зберегти свої позиції в урядуванні, не лише отримати посаду у місцевих органах влади, а якщо пощастить, то й зробити кар'єру якщо не на військовій службі, то цивільній. Держава й надалі розраховувала на дворянство яке отримуючи освіту, поповнювало зростаючі ряди бюрократії та армії. Вона потребувала фахівців для місцевого врядування з вищою або середньою освітою. Тоді як у цей самий час у Франції і Англії перевага традиційно віддавалася земельному і майновому цензу при обійманні виборних посад. У Росії ж враховувався і освітній рівень претендентів на голів місцевого самоврядування ${ }^{17}$.

Генерал-губернатор мав засвідчити рівень матеріального забезпечення родини, стаж та якість відбування батьком державної служби, i, як правило, такі клопотання закінчувалися результативно. Ілюстрацією подібних звернень $€$ прохання штабс-капітана Григорія Богачова до директора Київського кадетського корпусу аби той прийняв його онука на навчання за державний рахунок. Про своє матеріальне забезпечення вказав наступне. Меш- 
кає у приватному будинку, який не приносить жодних статків. Сам він поважного віку, має 88 років, дружині - 73 роки. Він, дружина та їх 23-річна донька можуть розраховувати лише на його військову пенсію. Син Богачова служить писарем в Управлінні ПівденноЗахідною залізниці, має п'ять дітей, тож не може обійтися без державної підтримки. Цю інформацію підтвердив і херсонський губернатор ${ }^{18}$.

Крім кадетських корпусів дворяни утримували власним коштом будинки виховання збіднілих дворян, дворянські пансіони. Один із них, а саме Полтавський будинок, успішно проіснував з 1805 по 1841 р. 1866 р. полтавське дворянство повернулося до обговорення заснування пансіону, однак зібрання не підтримало ідею його відновлення ${ }^{19}$. У такий спосіб чинили й інші дворяни, які впродовж $1860-\mathrm{x}-1870-\mathrm{x}$ років відмовилися утримувати при гімназіях пансіони, своєрідні закриті навчальні заклади, із власними вихователями i почесними опікунами.

Проте, переживши кризу ідентичності, дворянство почало куди активніше повертатися до закритих навчальних закладів, уважаючи, що загальноосвітня школа «дурно влияет» на виховання їхніх дітей. Молодих людей слід було відгородити від популярного серед гімназистів та студентів народницького руху з його «ходінням в народ», 3 нігілізмом, із відкиданням і запереченням батьківського авторитету. За даними судових процесів членами однієї лише «Народної волі» було $38,3 \%$ дворян ${ }^{20}$. А якщо говорити про початок XX ст., то переважна більшість студентства виявляла прихильність до соціалістичних політичних партій, частина - до ліберальних і абсолютна меншість - до консервативно-монархічних союзів ${ }^{21}$.

Дворянські пансіони почали відновлюватися за прикладом Москви. Одним 3 перших катеринославське дворянство розглянуло на своєму губернському зібранні питання про заснування при місцевій жіночій гімназії дворянського пансіону, у якому буде надаватися шляхетне виховання 22 .

1880 р. харківське дворянство звернулося до імператора про відкриття вже пансіонпритулку. Мету такого закладу вони пояснювали прагненням виховувати дітей вірними слугами батьківщини, за правилами справжньої моралі, добрих помислів, аби ті могли виконати свій громадський обов'язок ${ }^{23}$. На дворянських з'їздах не раз піднімалася проблема заснування спеціальних навчальних закладів для дітей дворян. На одному із них була обрана комісія для напрацювання питання про організацію пансіон-притулків, кількість яких би задовольнила бажання охочих там навчатися ${ }^{24}$. Але тоді Міністерство народної освіти ці прагнення не підтримало, бо було переконане у важливості всестанової освіти.

Зміну державної політики на підтримку дворянської освіти засвідчив закон від 25 травня 1899 р., згідно з яким Міністерство фінансів виділило 3 млн руб. для повсюдного запровадження пансіон-притулків ${ }^{25}$. Ишлося про те, що дворянським корпораціям надавалося право на їх заснування. Вони б функціонували окремо від навчального закладу і до них могли прийматися вихованці і гімназій, і реальних училищ. Перебували пансіон-притулки у подвійному віданні Міністерства народної освіти, на місцевому рівні - попечителя навчального округу й одночасно - під опікою дворянського зібранняя ${ }^{26}$. У пансіоні-притулку молодих людей забезпечували квартирою, столуванням, одягом, білизною, взуттям, навчальними книжками і посібниками. При прийомі до пансіонів віддавалася перевага тим дітям, а то й внукам спадкових дворян, чиї батьки служили на виборній службі, як-от: дворянській, земській, у державних установах із селянських справ. Якщо вже відслужили, то враховувалася їхня попередня служба, з бажаним дев'ятирічним терміном. I, головне, саме їхні діти могли розраховувати на безкоштовне навчання. Крім того, зверталася увага й на дітей тих збіднілих дворян, котрі продовжували мешкати у маєтках і займатися сільським господарством. Дворянські зібрання брали участь в укладанні статуту пансіон-притулку, формували його бюджет, зобов'язуючись вносити на його утримання половину коштів. Всі три міністерства - освіти, фінансів і внутрішніх справ - схвалювали проект статуту і вимагали конкретизувати джерела фінансування. Тільки в разі дворянського сприяння держава виділяла одноразовий внесок і щорічний такого розміру аби забезпечити його облаштування за умови браку дворянських коштів.

3 часом держава знову повернулася до цих пансіонів-притулків і переглянула вимоги до керівного складу та до вихователів. Починаючи з 1905 р., кожен 3 них отримував посаду директора, котрого обирало депутатське дворянське зібрання з осіб з вищою освітою. Запроваджувалася і посада почесного попечителя, висунуто підвищені вимоги до 
викладачів, якими могли працювати лише особи з середньою і вищою освітою. Їм було гарантоване матеріальне забезпечення і права державної служби ${ }^{27}$.

Не можна стверджувати, що всі дворяни з готовністю підтримали верховну владу, хоча більшість, як заявив один з делегатів четвертого з'їзду уповноважених дворянських корпорацій в 1908 р., була переконана, що дворянство, як ніякий інший стан, має дбати про майбутнє управління державою, а тому важливо підтримувати і вдосконалювати дворянську освіту. Й що лише об'єднуюча форма виховання і освіти сприятиме збереженню дворянських традицій ${ }^{28}$. I все ж, на початок царювання Миколи II лише у семи губерніях за ініціативою дворянських корпорацій були засновані пансіон-притулки. Через брак коштів пансіон-притулок у Полтаві був відкритий лише $1903 \mathrm{p}^{29}$, хоча про нього на з'їзді дворянських уповноважених говорилося набагато раніше. Представник від полтавського дворянства розповідав, що там зможуть навчатися діти і спадкових, і особистих дворян. Охочих виявилося багато і більшість була переконана у потребі збереження станової освіти.

Цього ж 1903 р. питання заснування дворянського пансіон-притулку розглянуло й Харківське губернське дворянське зібрання. Однак його відкриття відкладалося то через брак приміщення, то коштів. 1905 р. надзвичайне дворянське зібрання постановило, що не зручно звертатися до уряду про субсидію і варто почекати закінчення Російсько-японської війни. На 1911 р. не було й будівлі, яка задовольняла б і ціною, і призначенням. До цього питання дворянське зібрання поверталося ще не раз: 1913 р. було укладено його проект та передано на схвалення міській управі ${ }^{30}$. Подібний пансіон-притулок існував й у Чернігові.Підкреслимо, що при їх заснуванні дворянство досить активно вступало у боротьбу з державою за свої права на нерухому власність. Адже з переходом на всестанову освіту Міністерство народної освіти використовувало у загальнодержавних інтересах ті будівлі, що колись дворянство споруджувало на власні кошти. Тепер дворяни вимагали їх повернення, адже пансіон-притулок вважався окремим навчальним закладом, кожний із власним статутом, у якому навчання організовувалося згідно 3 місцевими традиціями, чисельністю учнів та викладачів. Обумовлювалися умови вступу, звільнення, розмір плати за навчання, обов’язки батьків перед пансіон-притулком, розмір і кількість стипендій.

Зверталася увага і на специфіку етнічної еліти, на яку поширювалась жалувана грамота російському дворянству, серед якої - татарська знать. При пансіоні Сімферопольської гімназії діяло відділення для підготовки десяти дітей мурз віком від 8 до 10 років до вступу у перший гімназійний клас. Крім викладання російської мови та арифметики, яке забезпечував наглядач, котрий знав дві мови, мулла знайомив також з татарською мовою та магометанським віровченням. Утримувалося це відділення цілком на кошти місцевого дворянства ${ }^{31}$.

Досить популярним ставало запровадження стипендій на дворянські кошти для дітей спадкових і особистих дворян, які здобували освіту як у станових, так і в нестанових вищих і середніх навчальних закладах. Як правило, на неї витрачалися дворянські кошти, спеціально зібрані дворянськими корпораціями. Розмір зборів становив по кілька копійок 3 кожної десятини землі чи іншої нерухомої власності, внаслідок чого запроваджувалося по кілька стипендій на повіт і кожна з них складала від 75 до 200 руб. Серед них часто були й іменні, якщо кошти на них виділяла одна особа, ім'я якої і присвоювалося стипендії. Більшість із них приурочувалися до важливих подій в імператорській родині, чи то шлюбів, чи днів народжень. Практикувалася й така форма, як використання для стипендій відсотків із спеціально заснованих капіталів.

Якщо говорити про освіту дівчаток знатного походження, то вони іiї здобували у інститутах шляхетних панянок: Полтавському, Харківському, Київському, Одеському, Керченському. Їх заснування також здійснювалося на дворянські кошти. Однак досить скоро всі вони перейшли у відомство імператриці Марії Федорівни. Спершу у кожному із них освіту отримували лише дівчатка шляхетського походження. Ось, Одеський надавав безкоштовну освіту дворянським донькам Херсонської, Катеринославської і Таврійської губерній та Бессарабської області. Там же могли навчатися й доньки військових і цивільних чиновників, служба яких відбувалася у цих губерніях та в Одеському і Керченському градоначальствах ${ }^{32}$. Полтавський інститут приймав на навчання доньок дворян і чиновників порівну 3 однойменної і Чернігівської губерній. Навчальні програми цих навчальних закладів орієнтувалися на те, щоб дівчатка отримували як «внутрішню», так і «зовнішню» освіту. Їх поєднання допомагало панночкам зробити в майбутньому гарну «партію» при одруженні. Плата за на- 
вчання зростала чи не щороку і у Харківському вона 1881 р. складала 350 руб. Такою ж вона була і у Київському. Їх об’єднувало спільне святкування днів народження Марії Федорівни ${ }^{33}$.

Рух жінок за емансипацію, що найбільше проявився у прагненні здобути освіту, а згодом і місце служби, викликав у значної частини дворянства психоментальне несприйняття. Один із сучасників у публіцистичні брошурі «Задачи дворянства», яких тоді з'явилося досить багато, писав, що у вимозі жінками рівних прав з чоловіками закладається багато шкідливого для самих жінок. Сама думка, що жінка не буде займатися домашнім господарством, свідчить про іï моральну розбещеність ${ }^{34}$. Лише наприкінці XIX ст. інтелігентна працююча дворянка стала звичним явищем ${ }^{35}$.

Реакцією на жіночу емансипацію було зменшення числа вихованок у інститутах шляхетних панянок. Зокрема, у Київському їх чисельність з 253 дійшла до 158 осіб. Певно, що на зменшення їх числа вплинуло відкриття жіночих гімназій, у яких навчання було не таким задисципліновим щодо поведінки, як у інституток. Аби зупинити відтік учениць, дирекція інституту 1878 р. пішла на небачене. Було дозволено приймати доньок не тільки почесних громадян і купців першої гільдії, а й дітей неплатників податків. Суттєво змінено програми дисциплін, їх викладання, поліпшено побутові умови, в тому числі і харчування $^{36}$. Розпочалася кампанія за заснування стипендій дворянським коштом, аби освіту змогли отримати дівчатка збіднілого дворянства ${ }^{37}$. Підтримкою держави почали активно користуватися ті з них, для кого державна служба була єдиним джерелом матеріального забезпечення. Виробився навіть механізм отримання там вакансій на навчання доньок державним коштом. До головноуправляючого Власної його величності канцелярії по установах імператриці Марії М. О. Протасова-Бахметьєва зверталися, як правило, повітові справники та їх помічники, судові слідчі, бездоганну службу яких повинні були засвідчити губернатори і генерал-губернатори. Чиновники повітового і губернського рівня були переконані, що держава зобов'язана дбати про освіту їхніх дітей, адже вони чесно відбувають державну службу. Предводителі дворянства також брали рекомендаційну участь в одговоренні кандидатур на отримання державних стипендій, зважаючи на бюджет і чисельність родини, глава якої не міг дати усім дітям пристойну освіту ${ }^{38}$. Як правило, прохання про зарахування супроводжувало посвідчення про сімейне матеріальне становище.

І все ж, було б неправильно стверджувати, що все дворянство одностайно прагнуло до збереження та примноження станової освіта. Певна його частина наполягала й, більше того, виділяла кошти на заснування професійних шкіл, зокрема ремісничих училищ, аби їх вчорашні кріпаки отримали професійні навики для роботи на підприємствах у їхніх маєтках ${ }^{39}$.

Підсумуємо. Чому ж дворянство обстоювало станову освіту? Вважаю, що основним було прагнення через неї зберегти соціальну ідентичність, яку йому різними шляхами тривалий час насаджувала верховна влада. У фокусі освіти збігалися спільність інтересів держави і дворянства. Впродовж століть саме дворянство було єдиним соціальним джерелом формування бюрократії, на яку держава покладала функції управління. Для цього освіта була уведена до категорії традиційних дворянських родинних цінностей. Насамперед йдеться про такі базові поняття: дворянин має бути освіченим аби службою виконувати свій обов'язок перед батьківщиною. Дворянська честь, патріотизм, особиста відданість престолу не були лише риторикою. Їх держава культивувала і дворянські родини, які здобули власне дворянство службою були переконані, що їх діти зможуть засвоїти цей набір, навчаючись у станових освітніх закладах, у яких вдало поєднувалося освіта і виховання. Були й другорядні чинники, а саме: побоювання, що всестанова освіта витіснить дворянство із державної служби, що примушувало його захищати, оберігати і плекати свою минулу спадщину і традиційні цінності й нагадувати престолу про власні заслуги. I це йому вдавалося, адже промисловці і банкіри, які часто були багатшими за стару еліту, прагнули отримати дворянське звання, а разом з ним орієнтувалися і на шляхетське виховання, яке відрізняло дворянське коло від недворянського.

${ }^{1}$ Павловский И. Ф. Исторический очерк Петровского полтавского кадетського корпуса (18401890). Полтава, 1890. С. 10-13.

2 Див. докладніше: Шандра В. Малоросійське генерал-губернаторство, 1802-1856: Функції, структура, архів. К., 2001. С. 120-121. 
${ }^{3}$ Наприклад, чернігівське дворянство 1861 р. виділило кошти для навчання в корпусі для десяти осіб. (Полное собрание законов Российской империи (далі ПСЗ РИ). Собр. 2-е. СПб., 1863. Т. 36. Отд. 1: 1861. № 36735).

${ }^{4}$ Павловский И. Ф. Исторический очерк Петровского полтавского кадетского корпуса. С. $96,100$.

${ }_{5}^{5}$ Барадачёв, А. Г. Цыбулькин В. В., Рожен Л. Н. Кадетские корпуса ХІХ - нач. ХХ вв.: украинское измерение. К., 2012. С. 104.

${ }^{6}$ Мысли и воспоминания поляка // Русская старина. 1906. Кн. 127. С. 673; Середонин С. М. Исторический обзор деятельности Комитета министров. СПб., 1902. Т. 3. Ч. 1. С. 308.

${ }^{7}$ Игнатьев А. А. Пятдесят лет в строю. М., 1986. Т. 1. С. 34.

${ }^{8}$ Объединённое дворянство. Съезды уполномоченных губернских дворянских обществ. 19061908. В 3 тт. М., 2001. Т. 2. Кн. 2: 1911-1912. С. 49.

${ }^{9}$ Картавцчов Л. В. Петровский полтавский кадетский корпус // Русская старина. 1890. Кн. 5.

${ }^{10}$ Павловский И. Ф. Исторический очерк Петровского полтавского кадетского корпуса. С. 30, 43, 73.

${ }^{11}$ Павловский И. Ф. К истории полтавского дворянства, 1802-1902: Очерки по архивным данным. Полтава, 1906. Вып. 1. С. 158-159.

${ }^{12}$ Там же. С. $153-154$.

${ }_{13}$ Иванова Н. А., Желтова В. П. Сословное общество Росссийской империи (XVIII - начало ХХ века). М., 2009. С. 162.

14 Козлов О. Родоводи: Антоновичів, Мосцепанових, Нарановичів. Огієвських, Терещенків, Харитоненків. Суми, 2006. С. 34.

15 Черниговского дворянского предводителя дворянства губернскому собранию дворянства доклады. Чернигов, 1893. С. 52.

${ }^{16}$ ПСЗ РИ. Собр. 3-е. СПб., 1902. Т. 19:1899. № 16771.

${ }^{17}$ Объединённое дворянство. Съезды уполномоченных губернских дворянских обществ. 19061908. В 3 тт. Москва, 2001. Т. 1: 1906-1908. С. 645.

18 Центральний державний історичний архів України, м. Київ (далі ЦДІАК України). Ф. 442. Оп. 523. Спр. 157. Арк. $1,8$.

${ }^{19}$ Павловский И. Ф. К истории полтавского дворянства. С. 131, 135, 136, 138.

${ }^{20}$ Волковинський В., Ніконова I. Революційний тероризм в Російській імперії і Україна. Друга половина XIX - початок XX ст. К., 2006. С. 25, 48.

${ }^{21}$ Иванов А. Е. Высшая школа России в конце XIX - начале XX века. М., 1991. С. 310-314.

22 Державний архів Одеської області. Ф. 1. Оп. 140 (1871 р.). Спр. 105. Арк. 7; Кочергін I. O. Соціальна трансформація катеринославського дворянства (друга половина XIX - початок XX ст.). Дніпропетровськ, 2015. С. 413.

${ }^{23}$ Илляшевич Л. В. Краткий очерк истории харьковского дворянства. Харьков, 1885. С. 153.

24 Объединённое дворянство. Съезды уполномоченных губернских дворянских обществ. Т. 1: 1906-1908. С. 540.

${ }^{25}$ ПСЗ РИ. Собр. 3-е. СПб., 1902. Т. 19. Отд. І: 1899. № 16950; Объединённое дворянство. Съезды уполномоченных губернских дворянских обществ. Т. 1: 1906-1908. С. 905.

${ }^{26}$ ПСЗ РИ. Собр. 3-е. СПб., 1902. Т. 19. Отд. 1: 1899. № 16950.

${ }^{27}$ ПСЗ РИ. Собр. 3-е. СПб., 1908. Т. 25. Отд. 1: 1905. № 26425.

28 Объединённое дворянство. Съезды уполномоченных губернских дворянских обществ. Т. 1: 1906-1908. С. 536.

${ }^{29}$ Павловский И. Ф. К истории полтавского дворянства. С. 139.

30 Харьковские губернские ведомости. 1903. 3 октября. С. 3; 1911. 11 мая. С. 3; 1913. 10, 24 декабря; Доклады харьковского губернского предводителя дворянства харьковскому губернскому дворянскому собранию. Харьков, 1906. С. 22.

${ }^{31}$ Блосфельдт Г. Сборник законов о российском дворянстве. СПб., 1901. С. 328-329.

${ }^{32}$ Там же. С. 326.

${ }^{33}$ Щелков К. П. Историческая хронология Харьковской губернии. Харьков, 1882. С. 299, 306; Захарченко М. М. История Киевского института благородных девиц (1838-1888). К., 1889. С. 47.

34 Ярмонкин В. Задачи дворянства. СПб., 1895. С. 8.

${ }^{35}$ Веременко В. А. Дворянская семья и государственная политика России (вторая половина XIX - начало XX в.). Изд. 2-е, допол. и испр. СПб., 2009. С. 633.

36 Захарченко М. М. История Киевского института благородных девиц (1838-1888). К., 1889. C. $47,51,84,85$.

37 Постановления Черниговского губернского собрания дворянства 1881 года. Чернигов, 1883. C. 8 .

${ }_{38}^{38}$ ЦДІАК України. Ф. 442. Оп. 626. Спр. 320. Арк. 3, 4; Оп. 622. Спр. 102; Оп. 627. Спр. 301.

39 Див.: Єсюнін С. Міста Поділля у другій половині XIX - на початку XX ст. Монографія. Хмельницький, 2015. С. 219. 